\title{
Reaction of grapevine rootstocks and cultivars to Meloidogyne incognita, M. arenaria and M. hapla
}

Vega-Callo, R. A., Tamo-Zegarra, J. J. and Bellé, C

DOI: 10.31047/1668.298x.v38.n1.29368

\begin{abstract}
SUMMARY
This study aimed to evaluate the reaction of six grapevine rootstocks (MGT 101-14, Ritcher 110, Paulsen 1103, K 5BB, SO4, Salt creek) and two cultivars (Quebranta and Torontel) to three species of the root-knot nematode (Meloidogyne incognita, M. arenaria and M.hapla). The experiment was performed as a completely randomized design with an $8 \times 3$ factorial scheme and six replicates per treatment. The experimental unit in each replicate comprised a grapevine cutting planted in $3 \mathrm{~kg}$ bags with sterilized soil. Cuttings were inoculated with 5000 eggs + juveniles (J2) of $M$. incognita, M. arenaria and $M$. hapla. Six months after inoculation, plants were removed from the bags, and the reaction was determined by evaluating the number of galls (NG), number of nematodes per gram of root (NNGR), and reproduction factor (RF). The evaluated rootstocks, MGT 101-14, Ritcher 110, Paulsen 1103, K 5BB, SO4 and Salt Creek, were resistant to $M$. incognita, $M$. arenaria and $M$. hapla, except for Salt creek, which was susceptible to the latter. The Quebranta and Torontel cultivars were susceptible to the Meloidogyne species under study.
\end{abstract}

Keywords: root-knot nematode; resistance; susceptibility; Vitis spp.

Vega-Callo, R. A., Tamo-Zegarra, J. J. y Bellé, C, 2021. Reacción de portainjertos y cultivares de vid a Meloidogyne incognita, $M$. arenaria y M. hapla. Agriscientia 38: 93-98

\section{RESUMEN}

El presente estudio se realizó para evaluar la reacción de seis portainjertos (MGT 101-14, Ritcher 110, Paulsen 1103, K 5BB, SO4, Salt creek) y dos cultivares de vid (Quebranta y Torontel) a tres especies del nematodo de la agalla (Meloidogyne incognita, $M$. arenaria and $M$. hapla). El experimento se realizó con un diseño completamente al azar con un esquema factorial de $8 \times 3$ y seis repeticiones por tratamiento. La unidad experimental en cada repetición estuvo constituida por una estaca de vid plantada en bolsas de $3 \mathrm{~kg}$ con sustrato esterilizado. Se inocularon las estacas con 5000 huevos + juveniles 
(J2) de $M$. incognita, $M$. arenaria y $M$. hapla. Seis meses después de la inoculación, las plantas se extrajeron de las bolsas y la reacción se determinó evaluando el número de agallas (NA), el número de nematodos por gramo de raíz (NNGR) y el factor de reproducción (FR). Los portainjertos evaluados, MGT 101-14, Ritcher 110, Paulsen 1103, K 5BB, SO4 y Salt Creek, fueron resistentes a $M$. incognita, $M$. arenaria y $M$. hapla, excepto Salt creek, que fue susceptible a este último. Los cultivares Quebranta y Torontel fueron susceptibles a las especies de Meloidogyne en estudio.

Palabras clave: nematodo de la agalla; resistencia; susceptibilidad; Vitis spp.

Vega-Callo, R. A. (ORCID: 0000-0003-4504-2960) y Tamo-Zegarra J. J. (ORCID: 0000-0001-7396-0430): Universidad Nacional de San Agustín de Arequipa, Calle Universidad s/n, Arequipa, Perú. Bellé, C. (ORCID: 0000-0003-2247-3207): Universidade Federal de Santa Maria, Av. Roraima $n^{\circ} 1000$ Cidade Universitária Bairro - Camobi, Santa Maria - RS, 97105-900, Rio Grande do Sul, Brasil. Correspondence to: crbelle@gmail.com

\section{INTRODUCTION}

Grapevine (Vitis sp.) is a predominant crop, extensively grown worldwide, with a strong productive trend in the last decade (Seccia, Santeramo and Nardone, 2015), with more than 21 million tons in the world. In Peru, agroclimatic conditions are favorable for the crop, and it is the fifth primary product in national agriculture, representing $4.6 \%$ of the gross value of agricultural production; areas of more intensive culture include the Ica, Piura and Lima regions, which represent $93 \%$ of the total national production. Until 2017, the Arequipa region had a harvested area of 1336 ha, with yields of $22139 \mathrm{~kg} \mathrm{ha}^{-1}$ (MINAGRI, 2019).

Meloidogyne species (root-knot nematode) is one of the major causes of grapevine damage (Somavilla, Bauer Gomes and Vera, 2012). It induces the formation of root galls, which restrict the absorption of water and nutrients as well as plant growth, predisposing it to the attack of other pathogens (Perry and Moens, 2014).

Meloidogyne incognita, $M$. javanica, $M$. ethiopica, $M$. arenaria, and $M$. hapla are the most important species that affect grapevine crops worldwide (Ferris, Zheng and Walker, 2012; 2013; Aballay and Vilches, 2015). In Peru, M. arenaria (Esterase phenotype - Est A2) was identified through its esterase isoenzyme in the Arequipa, Ica, and Piura regions, $M$. incognita (Est. I2) in Ica and $M$. javanica (Est. J3) in Ica and Piura (Varas, 2018).

The use of resistant rootstocks demonstrates characteristics that are very useful for resistance or tolerance to nematodes, additionally, worldwide more than $80 \%$ of all vineyards grow vines grafted onto rootstocks (Ollat, Bordenave, Tandonnet, Boursiquot and Marguerit, 2016). The rootstocks are resistant to phylloxera and soil fungi, they adapt to the physical and chemical properties of the soil (Somavilla et al., 2012), including tolerance to abiotic stress such as drought (Fort, Fraga, Grossi and Walker, 2017; Peccoux et al., 2018), salinity (Sohrabi, Ebadi, Jalali and Salami, 2017) and calcareous soils (Bavaresco and Lovisolo, 2015) and they provide greater vigor to the graft (Zhang, Marguerit, Rossdeutsch, Ollat and Gambetta, 2016).

In Peru, different rootstocks have been used, but there are no reports of a reaction with Meloidogyne species in the rootstocks and cultivars used under the conditions of the Arequipa region. This study aimed to evaluate the reaction of grapevine rootstocks and cultivars to $M$. incognita, $M$. arenaria and M. hapla.

\section{MATERIALS AND METHODS}

The experiment was conducted in a mesh house with a plastic cover (temperature of $25 \pm 5^{\circ} \mathrm{C}$ and humidity of $50 \pm 5 \%$, conditions that are suitable for grapevine cultivation) in the Phytopathology Laboratory of the Agronomy Faculty, National University of San Agustín (16 24' 32.79" S, 71 31' 18.87" W; 2365 m a.s.I.), Arequipa, Peru.

The experiment followed a completely randomized design, with an $8 \times 3$ factorial scheme, where the factors were the rootstocks, cultivars, 
and nematode species. There were six replicates per treatment and each replicate consisted of a bag with a grapevine plant.

A total of six rootstocks were used: MGT 101-14 (V. riparia $\times$ V. rupestris), Ritcher 110 (Vitis berlandieri $x$ Vitis rupestris), Paulsen 1103 (V. berlandieri $x$ $V$. rupestris), S04 ( $V$. berlandieri $x$ V. riparia), Salt Creek ( $V$. candicans $x$ V. rupestris), and $\mathrm{K}$ 5BB ( $V$. berlandieri $x V$. riparia). Two grapevine cultivars $(V$. vinifera) were used: Quebranta and Torontel. The cuttings were disinfected with Vitavax-300 and rooted in beds with a sand and pumice substrate $(2: 1)$. Once rooted, they were transplanted into $3 \mathrm{~kg}$ bags with a previously sterilized substrate of fine sand and promix (3:1).

M. incognita (Est 12), M. arenaria (Est A2), and $M$. hapla (Est H1) were used to infect grapevines of the Arequipa region. The identification of Meloidogyne species was made through the morphological characterization of the female perineal pattern (Hartmann and Sasser, 1985) and the biochemical characterization of the esterase isoenzyme through electrophoresis (Carneiro and Almeida, 2001). Meloidogyne species were kept in tomato plants where they multiplied (Solanum lycopersicum cv. 'Rio Grande') for a period of three months.

One month after transplantation, cuttings were inoculated with the nematode species. The eggs were extracted from the roots according to the method described by Hussey and Barker (1973). They were then suspended in water and inoculated, using a pipette, at a dose of 5000 eggs $+\mathrm{J} 2$ juveniles per bag, in four holes made in the soil around the plant. To control the viability of the inocula, susceptible tomato plants (Solanum lycopersicum cv. 'Rio Grande') were inoculated with a suspension of 5000 eggs $+\mathrm{J} 2$ juveniles of each Meloidogyne species and they were installed and conducted under the same conditions as the grapevine rootstocks and cultivars.

After six months, plants were collected to evaluate their reaction to Meloidogyne species. The aerial part was separated from the roots, carefully washed to determine the number of galls (NG). Subsequently, root systems were processed according to the method of Hussey and Barker (1973) to quantify the final population of nematodes (FP). From the final nematode population in the root system, calculations of number of nematodes per gram of root (NNGR) and the reproduction factor $(R F=$ final population / initial population) of Meloidogyne species were performed for each repetition. The grapevine rootstocks and cultivars were considered immune $(\mathrm{RF}=0)$, resistant $(\mathrm{RF}<1)$ and susceptible $(\mathrm{RF}>1)$ to the Meloidogyne species (Oostenbrink, 1966). The number of nematodes per gram of root was estimated by the ratio between the total number of nematodes and the total root mass (in grams) for each repetition.

The data for each nematode species were analyzed in the different rootstocks and cultivars (NG, NNGR, and RF variables were transformed into ). The respective analysis of variance (ANOVA) was performed, and means were compared with Duncan's multiple test $(p<0.05)$, the SAS ${ }^{\circ}$ University Edition software was used for data analysis.

\section{RESULTS AND DISCUSSION}

Results of ANOVA revealed an interaction in terms of NG, NNGR and RF between M. incognita, $M$. arenaria, M. hapla and the different rootstocks and cultivars evaluated. This interaction was corroborated with Duncan's Test $(p<0.05)$. Meloidogyne species induce gall formation and can reproduce in all the rootstocks and cultivars studied (Tables 1, 2 and 3).

None of the evaluated rootstocks were immune, since the three nematode species could reproduce in a limited way. Rootstocks infected with Meloidogyne species had an RF $=0.01$ to 0.73 (Tables 1, 2 and 3). Most were resistant; however, the 'Salt creek' rootstock, although resistant to $M$. incognita and $M$. arenaria, was susceptible to the attack by M. hapla, with an RF =1.39 (Table 3).

The Quebranta and Torontel cultivars were susceptible to the three species of Meloidogyne, with the highest RF of 1.6 to 3.49. Somavilla et al., (2012), Aballay and Vilchez (2015) reported a similar susceptibility of cultivars to $M$. incognita, $M$. ethiopica, M. hapla and M. javanica.

The SO4, Salt Creek, MGT-101-14, K5BB, Ritcher 110, and Paulsen 1103 rootstocks were resistant to $M$. incognita. According to Boubals (1992), the Paulsen 1103 rootstock is moderately resistant to $M$. incognita. Similarly, $\mathrm{SO} 4$ is resistant to $M$. incognita and $M$. arenaria (McKenry and Anwar, 2006). Somavilla et al. (2012) also reported that SO4, Salt Creek, and K 5BB are resistant to $M$. incognita. Moura et al. (2014) reported that MGT 101-14 and K 5BB are resistant to $M$. incognita. As described by Gutierrez- Gutierrez, Palomares-Rius, Jiménez-Díaz and Castillo (2011), the Ritcher 110 rootstock has a nematode-resistant reaction, which agrees with the results obtained in this experiment. The K5BB and Ritcher 110 rootstocks showed the lowest reproduction rates of $M$. incognita, with a $\mathrm{RF}=0.29$ and 0.28 , respectively. Quebranta 
Table 1. Number of galls (NG), number of nematodes per gram of root (NNGR), reproduction factor (RF), and reaction of rootstocks and cultivars to Meloidogyne incognita

\begin{tabular}{ccccc}
\hline \multirow{2}{*}{ Rootstocks and cultivars } & \multicolumn{4}{c}{ M. incognita } \\
\cline { 2 - 5 } & $\mathrm{NG}^{\mathrm{t}}$ & NNGR & $\mathrm{RF}^{\mathrm{v}}$ & Reaction $^{\mathrm{w}}$ \\
\hline SO4 & $3.50 \mathrm{~d}^{\mathrm{x}}$ & $188 \mathrm{bc}$ & $0.63 \mathrm{c}$ & $\mathrm{R}$ \\
Salt Creek & $8.33 \mathrm{c}$ & $116 \mathrm{c}$ & $0.67 \mathrm{c}$ & $\mathrm{R}$ \\
MGT 101-14 & $2.67 \mathrm{~d}$ & $171 \mathrm{bc}$ & $0.44 \mathrm{~cd}$ & $\mathrm{R}$ \\
K 5BB & $2.50 \mathrm{~d}$ & $143 \mathrm{bc}$ & $0.29 \mathrm{~d}$ & $\mathrm{R}$ \\
Ritcher-110 & $2.83 \mathrm{~d}$ & $46 \mathrm{c}$ & $0.28 \mathrm{~d}$ & $\mathrm{R}$ \\
Quebranta & $65.33 \mathrm{a}$ & $560 \mathrm{a}$ & $2.97 \mathrm{a}$ & $\mathrm{S}$ \\
Torontel & $33.50 \mathrm{~b}$ & $325 \mathrm{ab}$ & $2.28 \mathrm{~b}$ & $\mathrm{~S}$ \\
Paulsen 1103 & $10.17 \mathrm{c}$ & $209 \mathrm{~b}$ & $0.49 \mathrm{~cd}$ & $\mathrm{R}$ \\
Tomato cv. 'Rio Grande'y & 414.30 & 6932 & 8.4 & $\mathrm{~S}$ \\
CV (\%) & 18.01 & 28.61 & 6.92 & \\
\hline
\end{tabular}

'NG = Number of galls. ${ }^{\mathrm{N} N N G R}=$ Number of nematodes per gram of root. ${ }^{\mathrm{v}} \mathrm{RF}=$ Reproduction factor (RF = final population/ initial population). ${ }^{\text {"Reaction }}=(\mathrm{S})$ susceptible; (R) resistant; (I) immune. ${ }^{\times}$Means followed by the same letter in the columns are not significantly different by Duncan's test $(\mathrm{P}<0.05)$. ' Susceptible control for Meloidogyne incognita, Solanum lycopersicum' Rio Grande'. ${ }^{2} \mathrm{CV}=\mathrm{coefficient}$ of variation.

Table 2. Number of galls (NG), number of nematodes per gram of root (NNGR), reproduction factor (RF), and reaction of rootstocks and cultivars to Meloidogyne arenaria

\begin{tabular}{ccccc}
\hline \multirow{2}{*}{ Rootstocks and cultivars } & \multicolumn{4}{c}{ M. arenaria } \\
\cline { 2 - 5 } & NG $^{t}$ & $N^{\prime}$ RF $^{\mathrm{u}}$ & RF $^{v}$ & Reaction $^{w}$ \\
\hline SO4 & $0.83 \mathrm{~d}$ & $15.55 \mathrm{~cd}^{\mathrm{x}}$ & $0.06 \mathrm{e}$ & $\mathrm{R}$ \\
Salt Creek & $12.00 \mathrm{~b}$ & $174.91 \mathrm{~b}$ & $0.73 \mathrm{c}$ & $\mathrm{R}$ \\
MGT 101-14 & $0.33 \mathrm{~d}$ & $14.62 \mathrm{~d}$ & $0.02 \mathrm{e}$ & $\mathrm{R}$ \\
K 5BB & $0.67 \mathrm{~d}$ & $32.71 \mathrm{~cd}$ & $0.04 \mathrm{e}$ & $\mathrm{R}$ \\
Ritcher-110 & $3.83 \mathrm{c}$ & $73.33 \mathrm{bcd}$ & $0.32 \mathrm{~d}$ & $\mathrm{R}$ \\
Quebranta & $37.66 \mathrm{a}$ & $527.93 \mathrm{a}$ & $2.43 \mathrm{a}$ & $\mathrm{S}$ \\
Torontel & $19.50 \mathrm{~b}$ & $189.63 \mathrm{~b}$ & $1.6 \mathrm{~b}$ & $\mathrm{~S}$ \\
Paulsen 1103 & $2.00 \mathrm{~d}$ & $105.61 \mathrm{bc}$ & $0.14 \mathrm{of}$ & $\mathrm{R}$ \\
Tomato cv. 'Rio Grande'y & 535.7 & 1617.4 & 2.47 & $\mathrm{~S}$ \\
CV (\%) & 18.91 & 25.78 & 6.00 & \\
\hline
\end{tabular}

${ }^{\mathrm{N}} \mathrm{NG}=$ Number of galls. ${ }^{\mathrm{N} N N G R}=$ Number of nematodes per gram of root. ${ }^{\mathrm{v}} \mathrm{RF}=$ Reproduction factor $(\mathrm{RF}=$ final population/ initial population). ${ }^{\text {"Reaction }}=(\mathrm{S})$ susceptible; (R) resistant; (I) immune. ${ }^{\times}$Means followed by the same letter in the columns are not significantly different by Duncan's test $(\mathrm{p}<0.05)$. ' 'Susceptible control for Meloidogyne arenaria, Solanum lycopersicum' Rio Grande'. ${ }^{2} \mathrm{CV}=\mathrm{coefficient}$ of variation.

Table 3. Number of galls (NG), Number of nematodes per gram of root (NNGR), reproduction factor (RF), and reaction of rootstocks and cultivars to Meloidogyne hapla

\begin{tabular}{ccccc}
\hline \multirow{2}{*}{ Rootstocks and cultivars } & \multicolumn{3}{c}{ M. hapla } \\
\cline { 2 - 5 } & $\mathrm{NG}^{\mathrm{t}}$ & $\mathrm{NNGR}^{\mathrm{u}}$ & $\mathrm{RF}^{\mathrm{v}}$ & Reaction $^{\mathrm{w}}$ \\
\hline SO4 & $14.50 \mathrm{c}$ & $143.19 \mathrm{~b}$ & $0.44 \mathrm{c}$ & $\mathrm{R}$ \\
Salt Creek & $40.50 \mathrm{~b}$ & $425.67 \mathrm{ab}$ & $1.39 \mathrm{~b}$ & $\mathrm{~S}$ \\
MGT 101-14 & $0.50 \mathrm{~d}$ & $28.85 \mathrm{c}$ & $0.09 \mathrm{e}$ & $\mathrm{R}$ \\
5BB & $0.00 \mathrm{~d}$ & $0.12 \mathrm{c}$ & $0.01 \mathrm{e}$ & $\mathrm{R}$ \\
Ritcher-110 & $1.67 \mathrm{~d}$ & $25.24 \mathrm{c}$ & $0.12 \mathrm{e}$ & $\mathrm{R}$ \\
Quebranta & $92.16 \mathrm{a}$ & $534.92 \mathrm{a}$ & $3.49 \mathrm{a}$ & $\mathrm{S}$ \\
Torontel & $80.50 \mathrm{a}$ & $434.52 \mathrm{ab}$ & $3.37 \mathrm{a}$ & $\mathrm{S}$ \\
Paulsen 1103 & $13.33 \mathrm{c}$ & $368.67 \mathrm{ab}$ & $0.59 \mathrm{c}$ & $\mathrm{R}$ \\
Tomato cv. 'Rio Grande'y & 530.73 & 1928.93 & 2.53 & $\mathrm{~S}$ \\
CV (\%) & 15.03 & 20.60 & 5.03 & \\
\hline
\end{tabular}

${ }^{\mathrm{N}} \mathrm{NG}=$ Number of galls. ${ }^{\mathrm{N} N N G R}=$ Number of nematodes per gram of root. ${ }^{\mathrm{R} F}=$ Reproduction factor (RF $=$ final population/ initial population). ${ }^{\text {"Reaction }}=(\mathrm{S})$ susceptible; (R) resistant; (I) immune. ${ }^{\times}$Means followed by the same letter in the columns are not significantly different by Duncan's test $(\mathrm{p}<0.05)$. ' $S$ Susceptible control for Meloidogyne hapla, Solanum lycopersicum' Rio Grande'. ${ }^{2} \mathrm{CV}=\mathrm{coefficient}$ of variation. 
and Torontel cultivars show a high susceptibility, with an RF $=2.97$ and 2.28, respectively (Table 1). However, no other studies have indicated the susceptibility reaction of these cultivars, although similar behavior was evident to the cultivars evaluated by Somavilla et al. (2012), Aballay and Vilches (2015).

M. arenaria exhibited the lowest population levels in the experiment, with an $\mathrm{RF}=0.02$ to 0.73 . All rootstocks were considered resistant, as the RF was low compared to the previous Meloidogyne species evaluated. According to Somavilla et al. (2012), SO4, Salt Creek, and K 5BB were equally resistant to $M$. arenaria. Nevertheless, Paulsen 1103 was susceptible to the nematode, although this result may have been affected by crop conditions, such as soil characteristics, irrigation, and carrier clonal differences. Gutierrez-Gutierrez et al. (2011) indicated that Ritcher 110 and SO4 rootstocks are resistant to $M$. arenaria. Furthermore, Ferris et al. (2012) found that the MGT 101-14 rootstock was resistant and Ritcher 110 moderately resistant to $M$. arenaria. The authors also found Paulsen 1103 was susceptible, which is corroborated in this research. Moreover, Quebranta and Torontel cultivars, with an $\mathrm{RF}=2.43$ and 1.6 , respectively, are considered susceptible to $M$. arenaria (Table 2).

Regarding the reaction of the rootstocks to $M$. hapla, SO4, MGT 101-14, K 5BB, Ritcher 110, and Paulsen 1103 were resistant, except Salt Creek, which was susceptible, with an RF $=1.39$. According to Télis and Landa (2007), Salt Creek, SO4, and K5BB are resistant to M. hapla. Moreover, according to Aballay and Vilches (2015), SO4, K5BB, Paulsen 1103, and MGT 101-14 are not immune to $M$. hapla, but rather are more resistant than a grapevine cultivar. Ritcher 110 and SO4 rootstocks are resistant to $M$. hapla (GutierrezGutierrez et al., 2011). These reports differed from the results obtained in the experiment. On the contrary, Dalmasso and Cuani (1976) reported that SO4 is susceptible to M. hapla. Finally, Quebranta and Torontel cultivars presented the highest population levels, with a RF $=3.49$ and 3.37 , indicating susceptibility (Table 3 ).

\section{CONCLUSIONS}

Results indicate that $\mathrm{SO} 4, \mathrm{~K} 5 \mathrm{BB}$, Ritcher 110, MGT 101-14, Paulsen 1103, and Salt Creek rootstocks are resistant to $M$. incognita and $M$. arenaria. Only the Salt Creek rootstock is susceptible to M. hapla. The cultivars Quebranta and Torontel are susceptible to $M$. incognita, $M$. arenaria and M. hapla. As a conclusion, it is suggested to continue the studies of reaction to Meloidogyne with other rootstocks and root-knot nematodes, which is essential for a right choice of the rootstock to use.

\section{ACKNOWLEDGMENTS}

This research was financed by the Universidad Nacional de San Agustín de Arequipa, Peru, Grant Contract No. TP- 10 - 2019 - UNSA, Research Work to Opt for a Professional Degree.

\section{REFERENCES}

Aballay, E. and Vilches, O. (2015). Resistance assessment of grapevine rootstocks used in Chile to the root knot nematodes Meloidogyneethiopica, M. hapla, and M. javanica. Ciencia e Investigación Agraria, 42 (3), 407-413. DOI: https://dx.doi.org/10.4067/S071816202015000300009

Bavaresco, L. and Lovisolo, C. (2015). Effect of grafting on grapevine chlorosis and hydraulic conductivity. VITIS-Journal of Grapevine Research, 39 (3), 89. DOI: https://doi.org/10.5073/vitis.2000.39.89-92

Boubals, D. (1992). Ausujet de larésistance à l'anguillule de lavigne. Le Progrès Agricole et Viticole. 109 (2), 118.

Carneiro, R. and Almeida, M. (2001). Técnica de eletroforese usada no estudo de enzimas dos nematoides das galhas para identificação de espécies. Nematologia Brasileira, 25, 35-44.

Dalmasso, A. and Cuani, A. (1976). Resistance des porte-greffes de vignes a differentes populations du nematodo Meloidogyne hapla. Progres Agricole et Viticole 93 (25), 800-807.

Ferris, H., Zheng, L. and Walker, M. A. (2012). Resistance of grape rootstocks to plant-parasitic nematodes. Journal of Nematology, 44 (4), 377-386. Retrieved from: https://pubmed.ncbi.nlm.nih.gov/23482972/

Ferris, H., Zheng, L. and Walker, M. A. (2013). Soil temperature effects on the interaction of grape rootstocks and plant-parasitic nematodes. Journal of Nematology, 45, 49-57. Retrieved from: https://www. ncbi.nlm.nih.gov/pmc/articles/PMC3625132/pdf/49. pdf

Fort, K., Fraga, J., Grossi, D. and Walker, M. A. (2017). Early measures of drought tolerance in four grape rootstocks. Journal of the American Society for Horticultural Science, 142, 36-46. DOI: https://doi. org/10.21273/JASHS03919-16

Gutiérrez-Gutiérrez, C., Palomares-Rius, J. E., JiménezDíaz, R. M. and Castillo, P. (2011). Host suitability of 
Vitis rootstocks to root-knot nematodes (Meloidogyne spp.) and the dagger nematode Xiphinema index, and plant damage caused by infections. Plant Pathology, 60 (3), 575- 585. DOI: https://doi.org/10.1111/j.13653059.2010.02404.x

Hartmann, K. M. and Sasser, J. N. (1985). Identification of Meloidogyne species on the basis of differential hosts tests and perineal-patternmorphology. In: K. Barker, C. C. Carter and J. Sasser (Eds.). In An Advanced Treatise on Meloidogyne. Vol. II: Methodology (69-77). Raleigh, UnitedStates: Department of Plant Pathology, North Carolina State University.

Hussey, R. and Barker, K. R. (1973). A comparison of nematodes of collecting inocula for Meloidogynespp, including a new technique. Plant DiseaseReport, 57, 1025-1028.

McKenry, M. V. and Anwar, S. A. (2006). Nematode and grape rootstock interactions including an improved understanding of tolerance. Journal of Nematology, 38 (3), 312-318. Retrieved from: https://www.ncbi.nlm. nih.gov/pmc/articles/PMC2586707/

Ministerio de Agricultura y Riego de Perú (MINAGRI) (2019). La uva peruana: Una oportunidad en el Mercado Mundial. Retrievedfrom: https://cdn.www. gob.pe/uploads/document/file/419832/Informe-Uvaperuana.pdf

Moura, M. F., Tecchio, M. A., Dias-Arieira, C. R., Puerari, H. H., Cunha, T. P. L. and Chiamolera, F. M. (2014). Reaction of grape rootstocks to Meloidogyne incognita and $M$. javanica. Acta horticulturae, 1046, 109-112. DOI: https://doi.org/10.17660/Acta Hortic.2014.1046.12

Ollat, N., Bordenave, L., Tandonnet, J. P., Boursiquot, J. M. and Marguerit, E. (2016). Grapevine rootstocks: origins and perspectives. ActaHorticulturae,1136, 11-22. DOI: https://doi.org/10.17660/ActaHortic.2016.1136.2

Oostenbrick, M. (1966). Major characteristics of the relation between nematodes and plants. Mendelingen / Landbouhogeschool, Wageningen, 66, (1), 46.

Peccoux, A., Loveys, B., Zhu, J., Gambetta, G. A., Delrot, S., Vivin, P., Schultz, H. R., Ollat, N. and Dai, Z. (2018). Dissecting the rootstock control of scion transpiration using model-assisted analyses in grapevine. TreePhysiology, 38(7), 1026-1040. DOI: https://doi. org/10.1093/treephys/tpx153

Perry, R. and Moens, M. (Eds.) (2013). PlantNematology, Secondedition. Wallingford, Oxfordshire, UK: CABI Publishing.

Statistical Analysis System (SAS) (University Edition version) [Software].São Pablo, Brazil: SAS Institute. Retrieved from: https://www.sas.com/pt_br/software/ university-edition/download-software.html

Seccia, A., Santeramo, F. G. and Nardone, G. (2015). Trade competitiveness in table grapes: a global view. Outlook on Agriculture, 44 (2), 127-134. DOI: https:// doi.org/10.5367/oa.2015.0205

Sohrabi, S., Ebadi, A., Jalali, S. and Salami, S. A. (2017). Enhanced values of various physiological traits and VVNAC1 gene expression showing better salinity stress tolerance in some grapevine cultivars as well as rootstocks. ScientiaHorticulturae, 225, 317-326. DOI: https://doi.org/10.1016/j.scienta.2017.06.025

Somavilla, L., Bauer Gomes, C. and Quecini, M. V. (2012). Registro da ocorrência de Meloidogyne incognita no Porta-Enxerto 'Iac 766-Campinas' no Estado De Pernambuco e reação de porta-enxertos e de cultivares copa de videira a Meloidogyne spp. Revista Brasileira de Fruticultura, 34 (3), 750-756. DOI: https:// dx.doi.org/10.1590/S0100-29452012000300014

Téliz, D., Landa, B. B., Rapoport, H. F., Pérez Camacho, F., Jiménez-Díaz, R. M. and Castillo, P. (2007). Plantparasitic nematodes infecting grapevine in Southern Spain and susceptible reaction to root-knot nematodes of rootstocks reported as moderately resistant. PlantDisease, 91 (9), 1147-1154. DOI: https://doi. org/10.1094/PDIS-91-9-1147

Varas Huaroto, N. (2018). Caracterización de poblaciones peruanas del nematodo del nódulo de la raíz (Meloidogyne spp.) en vid (Vitis vinífera L.). Tesis de maestría no publicada, Universidad Nacional Agraria La Molina, Lima, Perú. Retrieved from: http:// repositorio.lamolina.edu.pe/handle/UNALM/3550

Zhang, L., Marguerit, E., Rossdeutsch, L., Ollat, N. and Gambetta, G. (2016). The influence of grapevine rootstocks on scion growth and drought resistance. Theoretical and Experimental Plant Physiology, 28 , 143-157. DOI: https://doi.org/10.1007/s40626-0160070-x 